\title{
EVALUATION OF ENDURANCE PHYSIOLOGICAL CHARACTERISTICS IN ROAD CYCLISTS
}

\author{
Inese Pontaga, Andris Konrads \\ Latvian Academy of Sports Education, Riga, Latvia
}

Inese Pontaga. PhD in Biomedical Sciences, Associate Professor, Head of the Department of Anatomy, Physiology and Biochemistry, Latvian Academy of Sports Education. Research interests - physiological characteristics of athletes trained in different sports, diagnostics of sport performance.

\begin{abstract}
The purpose of our investigation was to determine the most informative physiological characteristics to monitor training effect in highly qualified road cyclists.

Fourteen Latvian Olympic Team road cyclists with training experience from seven to nine years participated in the investigation voluntarily (their average age was $19.3 \pm 1.1$ years, height $-183.6 \pm 5.4 \mathrm{~cm}$, body mass $-73.4 \pm 3.8 \mathrm{~kg}$ ). The aerobic performance tests were carried out in the Latvian Olympic Team Laboratory at the initial and middle phase of their preparation period of training. The initial load of $27 \mathrm{~W}$ was increased every two minutes step by step by $12 \mathrm{~W}$. The cardiopulmonary diagnostic equipment was used to register the electrocardiograms and respiratory characteristics. The lactic acid concentration in the capillary blood was tested.

The maximal oxygen uptake (4.62 $\pm 0.40 \mathrm{l} / \mathrm{min}$ and $63.2 \pm 4.8 \mathrm{ml} / \mathrm{kg} \cdot \mathrm{min}$ ) and power output (376 $\pm 36 \mathrm{~W}$ and $5.13 \pm 0.44 \mathrm{~W} / \mathrm{kg}$ ) in the cyclists were significantly lower in comparison with the data received by other authors. At the initial or middle phase of the preparation period of training these characteristics did not reach their maximal values. The oxygen uptake (3.85 $\pm 0.30 \mathrm{l} / \mathrm{min}$ and $52.6 \pm 3.7 \mathrm{ml} / \mathrm{kg} \cdot \mathrm{min})$ and power output $(296 \pm 28 \mathrm{R}$ and $4.04 \pm 0.33 \mathrm{~W} / \mathrm{kg}$ ) at the anaerobic threshold intensity load were in a good agreement with the data of other investigators. These characteristics depend on the central and peripheral mechanisms of aerobic capacity in the cyclists, and are useful in the estimation and monitoring of the endurance performance. The data reported by different authors of aerobic threshold physiological characteristics in highly qualified cyclists were contradicting, which can be explained by different test protocols and differences in the rate of lactate accumulation in the capillary blood, especially in the initial phase of the test. Our investigations showed that the oxygen uptake was $2.57 \pm 0.35 \mathrm{l} / \mathrm{min}$ and $35.0 \pm 4.7 \mathrm{ml} / \mathrm{kg} \cdot \mathrm{min}$, and power output was $182 \pm 36 \mathrm{~W}$ and $2.48 \pm 0.47 \mathrm{~W} / \mathrm{kg}$.

The mechanical efficiency $(21.9 \pm 1.2 \%)$ and economy of cycling movements $(4.602 \pm 0.268 \mathrm{~kJ} / \mathrm{l})$ in the cyclists reached their maximal values at the anaerobic threshold, which is the intensity of load specific to road cycling. It proves high homogeneity of the mechanical efficiency and economy of movements among the cyclists, and lack of the significant correlation between these characteristics and the power output on the bicycle ergometer ( $r=0.19$ and 0.20 , respectively; $p>0.05$ ).
\end{abstract}

Keywords: cycling, aerobic capacity, work mechanical efficiency, aerobic and anaerobic thresholds.

\section{INTRODUCTION}

$\mathrm{P}$ rofessional road cycling is a long-duration, high intensity sport. Thus it requires that athletes possessed high aerobic capacity because the average load intensity during the race is $89-93 \%$ (Bourdon, 2000) or approximately $90 \%$ (Lucia et al., 2001) from the maximal oxygen uptake $\left(\mathrm{VO}_{2 \max }\right)$ intensity load. Correlations between physiological characteristics (oxygen uptake and power output) and the endurance performance are more close at an aerobic (AeT) and anaerobic
(AnT) threshold intensity load than at the $\mathrm{VO}_{2 \max }$ intensity load (Jacobs, 1986; Yoshida et al., 1987; Tanaka, Matsuura, 1984). For example, Craig et al. (1993) determined that correlation between the relative oxygen uptake at $\mathrm{AeT}$ and $4000 \mathrm{~m}$ race time was higher than the correlation between the relative $\mathrm{VO}_{2 \max }$ and the same race time. Studies of J. H. Ivy et al. (1980) and S. Aunola et al. (1988) have demonstrated that blood lactate transition thresholds indices reflect the muscle metabolic 
status or peripheral component of the oxygen transport system. Saltin (1985) determined $\mathrm{VO}_{2 \max }$ only by the central aerobic capacity mechanisms. Highly qualified athletes show very little or no improvement of $\mathrm{VO}_{2 \max }$ during training, but the oxygen uptake at the AeT and AnT continue to improve and allow to monitor the training effect (Bourdon, 2000).

Nevertheless, there is a great contradiction concerning the different AeT and AnT determination methods (Lucia et al., 2001). Some methods are based on the blood lactate concentration measurement, but others - on the lungs ventilation variables. Some authors have chosen long protocols (four to five minutes of every load step) to determine the break points in the lactate concentration - power output curve.

The break points are associated with a more rapid rise in the blood lactate concentration above the rest level (AeT or lactate threshold) and a very rapid rise of the lactate concentration in the blood - typically between 2.5 and $5.5 \mathrm{mmol} / \mathrm{l}$ (Bourdon, 2000) (AnT or onset of blood lactate concentration accumulation OBLA). Other authors have reported the use of ventilation parameters during shorter, ramp - like protocols (ten seconds to one minute increment of every load step) to determine the workload at which the break points in the ventilation - oxygen uptake curve occurs. This is a noninvasive testing method, but it has a tendency to underestimate athletes' training intensity (Plato et al., 2008).

The high level of aerobic capacity is necessary to achieve results in the endurance sports, and therefore its value is high and very similar in all elite endurance athletes. Possibility to win also depends on another condition: an economy of movements - the ability of the athlete to cover a distance in a given high speed with smaller uptake of oxygen (Shave, Fanco, 2006).

The purpose of our investigation was to determine the most informative physiological characteristics to monitor training effect in highly qualified road cyclists.

\section{METHODS}

Fourteen Latvian Olympic Team road cyclists were informed of the possible test risks and participated in the investigation voluntarily. The study was performed in conformity with the standards of the Ethics Committee of the Latvian Council of Sciences. Training experience of the cyclists was from seven to nine years. The aerobic performance tests of every cyclist were carried out once or twice a year in the Latvian Olympic Team Laboratory at the initial and middle phases of the preparation period of training. Two cyclists were tested five times, one - four times, one three times, two - twice, but eight cyclists only once. Before the tests the anthropometric characteristics were measured: the average age of the cyclists was $19.3 \pm 1.1$ years, the height $183.6 \pm 5.4 \mathrm{~cm}$, the body mass $-73.4 \pm 3.8 \mathrm{~kg}$ and the body mass index $-21.7 \pm 1.1 \mathrm{~kg} \mathrm{~m}$.

Every cyclist performed incremental load test on a mechanical bicycle ergometer (Monark, Sweden). Initial load intensity was $27 \mathrm{~W}$, but then it was increased every two minutes step by step by $12 \mathrm{~W}$. Every athlete performed the test to exhaustion. A cardiopulmonary diagnostic equipment "Oxygen Mobile Via Sys" (Via Sys Healthcare GMBH, Germany) was used to register the electrocardiogram and the respiratory characteristics. In our investigation we used the following characteristics: heart rate (beats per minute), volume of oxygen uptake (litres per minute), volume of expired carbon dioxide (litres per minute), respiratory quotient, and workload on the bicycle ergometer. The average values of all characteristics in the last minute of each load step were calculated. Gas analyzers were calibrated before and after each test. Lactic acid concentration in the capillary blood was detected by a special lactate analyzer "Biosen 5030" (EKG - diagnostic, Germany). The lactic acid concentration in the capillary blood was determined every two minutes (at the end of every load intensity step).

The average aerobic performance characteristics were determined at AeT intensity load. It was the workload, when the lactic acid concentration started to increase above the rest level. A break point was seen in the relationship between the workload on the ergometer and the lactic acid concentration in the capillary blood (Coyle, 1995). They were determined at the AnT intensity workload (onset of the blood lactate accumulation), when the lactic acid concentration in the capillary blood rapidly increased (it was below or close to $4 \mathrm{mmol} / \mathrm{l}$ ). The break point was seen in the relationship between the bicycle workload and concentration of the lactic acid in the blood (Sjodin, Jacobs, 1981). Rapid increase of the lactic acid concentration was observed, when the workload exceeded the AnT level due to intensive anaerobic glycolysis in the muscles fibers in providing ener- 
gy. The same aerobic performance characteristics were determined at the maximal oxygen uptake load.

Using the respiratory characteristics (exchange of gases) of the oxygen uptake volume and volume of carbon dioxide expiration per minute, the respiratory quotient was determined. Thermal equivalents of the oxygen for the certain respiratory quotients values were taken from the publication of W. D. McArdle et al. (2000). Then we calculated the energy expenditure for every cyclist in Joules ( $\mathrm{J}$ ) in one minute at the certain workload (the AeT and AnT level loads). Later we calculated the energy expenditure in one second - in $\mathrm{J} / \mathrm{s}=\mathrm{W}$ (Joule per second $=$ Watt). The amount of energy expenditure used for the mechanical work production on the ergometer was calculated in \% (the workload determined in the test $\mathrm{P}$ in $\mathrm{W}$ ) from all energy expenditure per second (En). It was the mechanical efficiency (ME) of every cyclist: $\mathrm{ME}=\mathrm{P}(\mathrm{W}) 100 /$ En (W); \%.

Using the data of the oxygen uptake $\left(\mathrm{VO}_{2}\right.$ in $\mathrm{l} / \mathrm{min}$ ) and the mechanical workload on the ergometer ( $\mathrm{P}$ in $\mathrm{W})$, we calculated the economy of movements (EC) of cyclists at the AeT and AnT load intensities (Moseley et al., 2004): $\mathrm{EC}=\mathrm{P}(\mathrm{W}$ ) $0.06 / \mathrm{VO}_{2}$ (l/ $\left.\mathrm{min}\right) ; \mathrm{kJ} / \mathrm{l}$.

The average values and the standard deviations for all characteristics were calculated. Student's $t$-test for paired data groups was employed to determine the differences between the physiological characteristics at AeT and AnT, and the maximal intensity loads. The differences were considered to be statistically significant at $\mathrm{p}<0.05$. Correlation and linear regression analyses were used to determine the relationships between the different physiological characteristics and the power output on the ergometer $\left(\mathrm{S}_{\mathrm{xy}}\right.$ - error of regression equation; $\mathrm{r}$ - coefficient of correlation; $\mathrm{p}$ - probability level).

\section{RESULTS}

The average endurance performance characteristics at the different intensities of loads (AeT, AnT and the maximal $\mathrm{VO}_{2}$ loads) are included in Table 1. Greater power output caused the increase of the absolute and relative $\mathrm{VO}_{2}$. The average work mechanical efficiency and the economy of movements on the ergometer were significantly higher at the AnT than at AeT load $(\mathrm{p}<0.0001)$.

The correlations between $\mathrm{VO}_{2}$ and ergometer power output were significant at AeT $(r=0.89$; $\mathrm{p}<0.0001)$, AnT ( $\mathrm{r}=0.89 ; \mathrm{p}<0.0001)$ and at the maximal $\mathrm{VO}_{2}$ load $(\mathrm{r}=0.80 ; \mathrm{p}<0.0001)$. The relationships between the absolute $\mathrm{VO}_{2}$ and the power output are shown in Fig. 1.

The correlations between relative $\mathrm{VO}_{2}$ and the ergometer power output were not so high than at the absolute $\mathrm{VO}_{2}$ : at AeT, AnT and at the maximal $\mathrm{VO}_{2}$ load, $\mathrm{r}=0.79$; $\mathrm{p}<0.0001, \mathrm{r}=0.58$; $\mathrm{p}<0.003$ and $\mathrm{r}=0.67 ; \mathrm{p}<0001$ respectively. The

\begin{tabular}{|c|c|c|c|}
\hline $\begin{array}{ll} & \text { Intensity of load } \\
\text { Characteristic } & \end{array}$ & AeT & AnT & $\mathbf{V O}_{2 \max }$ \\
\hline Power, W & $182 \pm 36$ & $296 \pm 28$ & $376 \pm 36$ \\
\hline Relative power, W / kg & $2.48 \pm 0.47$ & $4.04 \pm 0.33$ & $5.13 \pm 0.44$ \\
\hline Oxygen uptake, l / min & $2.57 \pm 0.35$ & $3.85 \pm 0.30$ & $4.62 \pm 0.40$ \\
\hline Relative oxygen uptake, $\mathrm{ml} / \mathrm{kg} \cdot \mathrm{min}$ & $35.0 \pm 4.7$ & $52.6 \pm 3.7$ & $63.2 \pm 4.8$ \\
\hline Heart rate, beats / min & $127 \pm 10$ & $167 \pm 7$ & $188 \pm 9$ \\
\hline Work mechanical efficiency, \% & $20.5 \pm 1.9$ & $21.9 \pm 1.2$ & - \\
\hline Economy of movements, kJ / l & $4.218 \pm 0.412$ & $4.602 \pm 0.268$ & - \\
\hline
\end{tabular}

Table 1 . Aerobic capacity and work mechanical efficiency characteristics at AeT, AnT and $\mathrm{VO}_{2 \max }$ intensity load on the bicycle ergometer

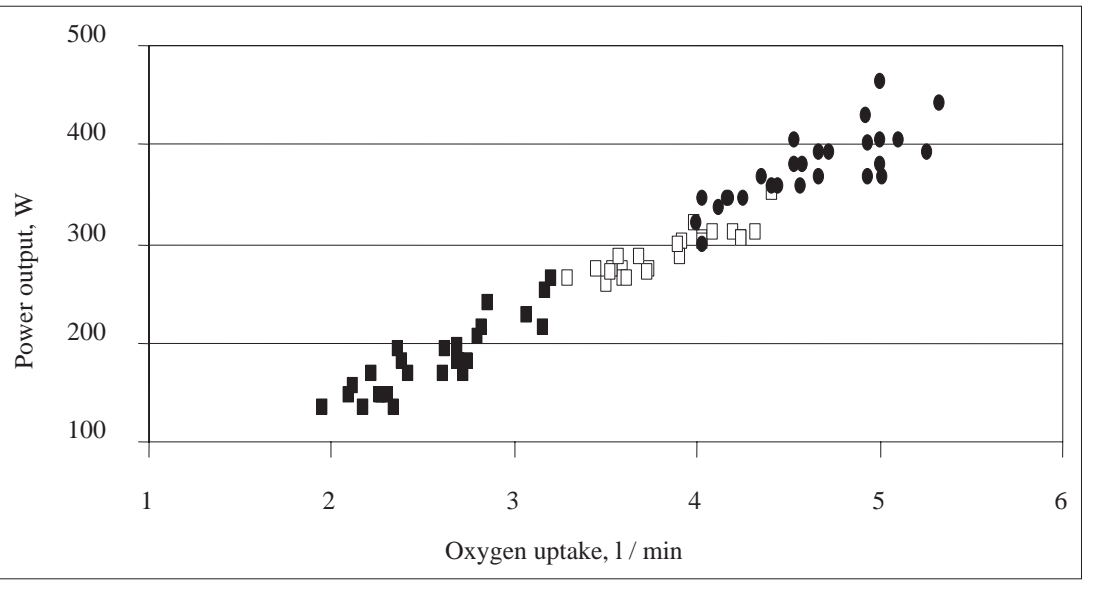

Figure 1. Relationship between absolute oxygen uptake and power output

Notes. 1) - at AeT load the relationship was characterized by equation: $\mathrm{P}_{\text {ае }}=91.91 \cdot \mathrm{VO}_{2}(\mathrm{l} / \mathrm{min})-54.75 ; \mathrm{W}$; $\mathrm{S}_{\mathrm{xy}}=16.86 \mathrm{~W} ; \mathrm{r}=0.89 ; \mathrm{p}<0.0001$; where $\mathrm{P}_{\mathrm{ae}}$ - power output at AeT load; $\mathrm{VO}_{2}-\mathrm{ab}$ solute oxygen uptake;

2) $\square-$ at AnT load $P_{\text {an }}=39.99+65.11 \mathrm{VO}_{2}$ $(\mathrm{l} / \mathrm{min}) ; \mathrm{W} ; \mathrm{S}_{\mathrm{xy}}=10.83 \mathrm{~W} ; \mathrm{r}=0.89$; $\mathrm{p}<0.0001$; where $\mathrm{P}_{\mathrm{an}}-$ power output at the AnT load;

3) - - at maximal $\mathrm{VO}_{2}$ load $\mathrm{P}_{\max }=35.52+73.52 \cdot \mathrm{VO}_{2 \max }(\mathrm{l} / \mathrm{min}) ; \mathrm{W}$; $\mathrm{S}_{\mathrm{xy}}=22.03 \mathrm{~W} ; \mathrm{r}=0.80 ; \mathrm{p}<0.0001$; where $\mathrm{P}_{\max }$ - power output at the AeT load. 
Figure 2. Relationship between relative oxygen uptake and power output
Notes. 1) - - at AeT intensity load the relationship $\mathrm{P}_{\mathrm{ae}}=6.09 \cdot \mathrm{VO}$ 2rel $(\mathrm{ml} / \mathrm{kg} \cdot \mathrm{min})-31.63, \mathrm{~W} ; \mathrm{S}_{\mathrm{xy}}=22.33 \mathrm{~W}$; $\mathrm{r}=0.79 ; \mathrm{p}<0.0001$; where $\mathrm{VO}_{2 \text { rel }}$ - relative oxygen uptake;

2) $\square-$ at AnT intensity load $\mathrm{P}_{\text {an }}=110.78+3.40 \cdot \mathrm{VO}_{2 \text { rel }}(\mathrm{ml} / \mathrm{kg} \cdot \mathrm{min})$; $\mathrm{W} ; \mathrm{S}_{\mathrm{xy}}=19.04 \mathrm{~W} ; \mathrm{r}=0.58 ; \mathrm{p}<0.003$;

3) - - at the maximal $\mathrm{VO}_{2}$ load $\mathrm{P}_{\max }=56.98+5.04 \cdot \mathrm{VO}_{2 \max \text { rel }}(\mathrm{ml} / \mathrm{kg} \cdot \mathrm{min})$, $\mathrm{W} ; \mathrm{S}_{\mathrm{xy}}=27.60 \mathrm{~W} ; \mathrm{r}=0.67 ; \mathrm{p}<0.0002$.

Figure 3. Relationship between work mechanical efficiency and power output

Notes. 1) - - at AeT intensity load $\mathrm{P}_{\mathrm{ae}}=15.04 \cdot \mathrm{ME}(\%)-126.41 ; \mathrm{W}$; $\mathrm{S}_{\mathrm{xy}}=23.03 \mathrm{~W} ; \mathrm{r}=0.78 ; \mathrm{p}<0.0001$; where $\mathrm{P}_{\mathrm{ae}}$ - power output at AeT load; ME - ergometer work mechanical efficiency;

2) $\square-$ at AnT intensity load the significant relationship was not determined.

Figure 4. Relationship between economy of cycling movements and power output
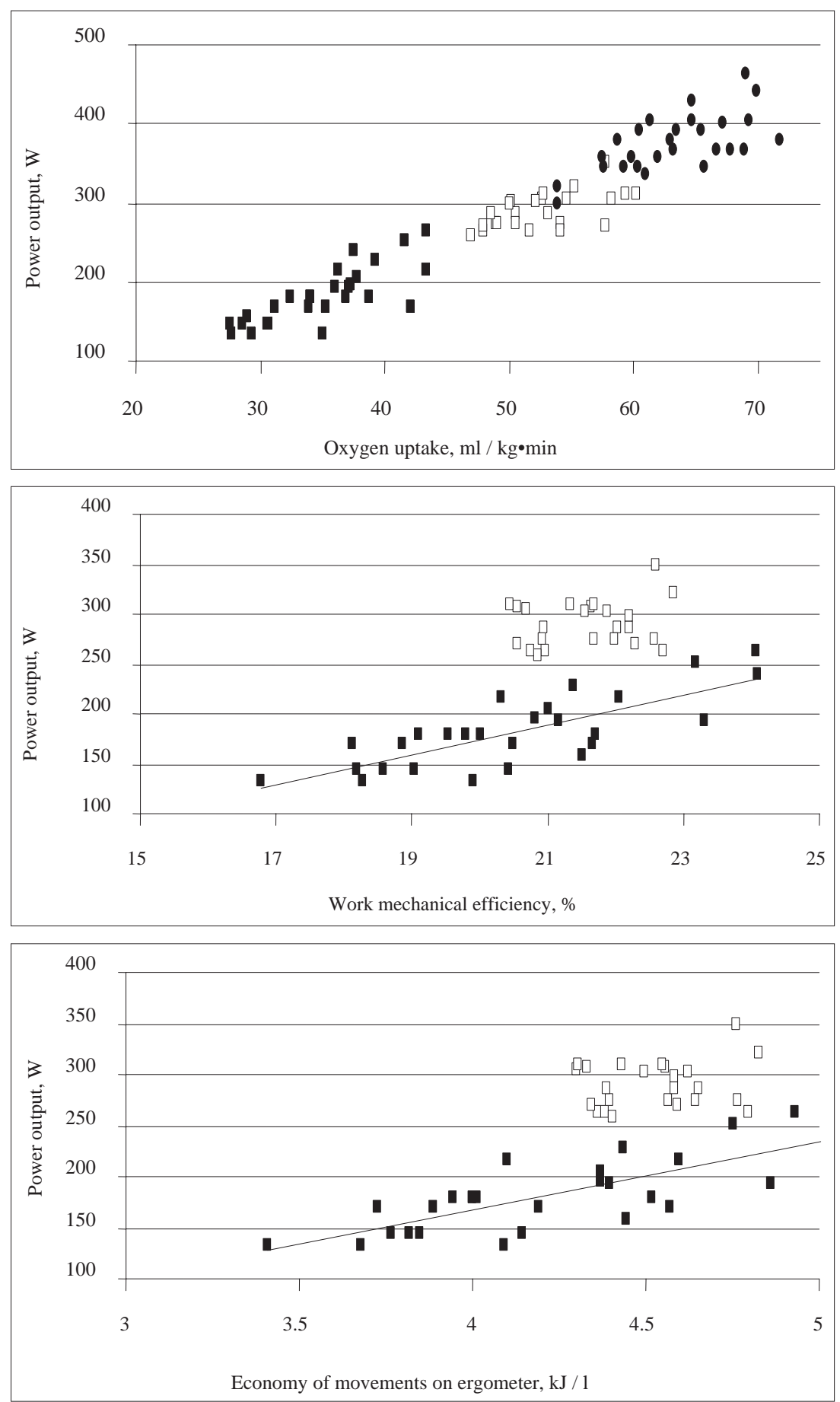

Economy of movements on ergometer, $\mathrm{kJ} / \mathrm{l}$
Notes. 1) - - at AeT intensity load $\mathrm{P}_{\mathrm{ae}}=66.70 \cdot \mathrm{EC}\left(\mathrm{kJ} / 1 \mathrm{lO}_{2}\right)-99.54, \mathrm{~W}$; $\mathrm{S}_{\mathrm{xy}}=23.77 \mathrm{~W} ; \mathrm{r}=0.76$; $\mathrm{p}<0.0001$; where $\mathrm{P}_{\mathrm{ae}}$ — power output at AeT load; EC — the economy of movements;

2) $\square-$ at AnT intensity load the significant relationship was not determined. relationships between the relative $\mathrm{VO}_{2}$ and the power output are shown in Fig. 2.

There was a positive correlation between the bicycle work mechanical efficiency and power production at the AeT intensity load $(\mathrm{r}=0.78$; $\mathrm{p}<0.0001$ ). At the AnT intensity load the correlation between these two variables was not significant $(r=0.20$; $p>0.05)$, Fig. 3 .

The positive correlation was detected between the economy of movements and power production at the AeT intensity load $(r=0.76 ; p<0.0001)$. At the AnT intensity load the correlation between the economy of movements and the power output was not significant $(r=0.19 ; \mathrm{p}>0.05)$, Fig. 4.

\section{DISCUSSION}

The anthropometric characteristics of the young highly qualified road cyclists of Latvia are in a good agreement with the characteristics of modern adult champions, who are approximately $180 \mathrm{~cm}$ tall with the average body weight of $70 \mathrm{~kg}$ (Lucia et al., 2001). For example, Australian $20.1 \pm 1.7$ years old cyclists are $179.3 \pm 3.5 \mathrm{~cm}$ 
tall and their body mass is $75.3 \pm 6.0$ (Craig et al., 1993).

Average values of maximal power output depend on the used test protocol. If the tests are with four or five minute increment, the maximal power output is from 400 to $500 \mathrm{~W}(6.0-6.5 \mathrm{~W} / \mathrm{kg})$ (Lucia et al., 2000). If the used protocols are shorter (ramp tests), the maximal produced power is higher than $500 \mathrm{~W}$ (6.5-7.5 W / kg) (Lucia et al., 1999; Lucia et al., 2000). The maximal power produced by our cyclists is lower: $376 \pm 36 \mathrm{~W}(5.13 \pm 0.44 \mathrm{~W} / \mathrm{kg})$. The average $\mathrm{VO}_{2 \max }$ in the Italian professional cyclists is from 5.0 to $5.5 \mathrm{l} / \mathrm{min}(70-80 \mathrm{ml} / \mathrm{kg} \cdot \mathrm{min}$ ) (Lucia et al., 1999; Padilla et al., 1999). In the highly qualified Australian cyclists $\mathrm{VO}_{2 \max }$ is slightly lower $5.13 \pm 0.36 \mathrm{l} / \mathrm{min}(68.5 \pm 6.4 \mathrm{ml} / \mathrm{kg} \cdot \mathrm{min})$ (Craig et al., 1993), but in our cyclists $\mathrm{VO}_{2 \max }$ is much lower $-4.62 \pm 0.40 \mathrm{l} / \min (63.2 \pm 4.8 \mathrm{ml} / \mathrm{kg} \cdot \mathrm{min})$. It is possible to explain that by their younger age, shorter training experience, testing at the initial part of the preparation phase of training and lower qualification in comparison with the world level cyclists.

There is a small amount of data concerning AeT physiological characteristics in high level cyclists. In the Australian cyclists the average power output is $203 \pm 28 \mathrm{~W}$ $(2.70 \pm 0.49 \mathrm{~W} / \mathrm{kg}), \mathrm{VO}_{2}=2.92 \pm 0.29 \mathrm{l} / \mathrm{min}$ $\left(\mathrm{VO}_{2 \mathrm{rel}}=38.8 \pm 5.2 \mathrm{ml} / \mathrm{kg} \cdot \mathrm{min}\right)$ and the heart rate is $144 \pm 11$ beats per minute (Craig et al., 1993). These characteristics are significantly higher than in our investigation (see Table 1), which can be explained by different test protocols or lower qualification of our cyclists. Craig et al. (1993) started the test protocol with the load of $100 \mathrm{~W}$ and increasing it by $50 \mathrm{~W}$ every five minutes; the initial load in our protocol is only $27 \mathrm{~W}$ with slower increasing by $12 \mathrm{~W}$ every two minutes. It may influence the rate of lactate accumulation in the capillary blood, especially in the initial part of the test.

The physiological characteristics of the Australian cyclists at AnT load - the average power output $=293 \pm 30 \mathrm{~W}(3.88 \pm 0.61 \mathrm{~W} / \mathrm{kg})$, $\mathrm{VO}_{2}=4.08 \pm 0.34 \mathrm{l} / \mathrm{min}\left(\mathrm{VO}_{2 \mathrm{rel}}=54.1 \pm 6.1 \mathrm{ml} / \mathrm{kg} \cdot \mathrm{min}\right)$ and the heart rate $=172 \pm 9$ beats $/ \mathrm{min}$ (Craig et al., 1993) are in good agreement with our cyclists characteristics (see Table 1). R. D. Telford et al. (1990) detected slightly higher power output in cyclists at AnT intensity load - $325 \mathrm{~W}$.

L. Moseley et al. (2004) determined that the ME of workload remains the same in the world - class and recreational cyclists. It varies between 18 and $19 \%$ at $165 \mathrm{~W}$ and the maximal power output on the ergometer. From the data of other authors (Coyle et al., 1992) its value varied in wider range: from 18 to 23\%. The average work ME of our cyclists at the AnT intensity load $=21.9 \pm 1.2 \%$ is significantly greater in comparison with its value $=20.5 \pm 1.9 \%$ at the AeT load ( $<0.0001)$. At AeT the load ME varied from 17 to $24 \%$, and the significant relationship between the work ME and the power output on ergometer is determined (see Fig. 3). At the AnT intensity load the work ME variations are much smaller - from 20.5 to 23\%. The significant correlation between the work ME and the power output is not determined.

Similar tendencies are observed in cycling EC: the average EC on the ergometer at the AnT intensity load $=4.602 \pm 0.268 \mathrm{~kJ} / \mathrm{l}$ is significantly greater than its value $=4.218 \pm 0.412 \mathrm{~kJ} / \mathrm{l}$ at the AeT load ( $<$ 0.0001). The significant correlation between EC and the power production is detected only at the AeT load, but at the AnT load it is not determined (see Fig. 4.). It not means that EC is not important for high power output and cycling performance. N. P. Craig et al. (1993) detected no significant correlation between cycling EC and performance. Other authors determined lack of significant correlation between running EC and the performance (Bulbulian et al., 1986; Deason et al., 1991). It is possible to explain that by high homogeneity of the cycling EC among qualified cyclists at the AnT intensity load, which is the specific workload intensity for the road cyclists (Craig et al., 1993). B. Ferdinandez-Garcia et al. (2000) measured the intensity of exercises during road cycling competitions Tour de France and Vuelta a Espana, and determined that greatest time of the race is performed in the load intensity between 70 and $90 \%$ of the $\mathrm{VO}_{2 \max }$ intensity load. It coincides with AnT load intensity.

\section{CONCLUSIONS}

1. The maximal oxygen uptake $(4.62 \pm 0.40 \mathrm{l} / \mathrm{min}$ and $63.2 \pm 4.8 \mathrm{ml} / \mathrm{kg} \cdot \mathrm{min}$ ) and power output (376 $\pm 36 \mathrm{~W}$ and $5.13 \pm 0.44 \mathrm{~W} / \mathrm{kg}$ ) in our cyclists are not high. Due to the testing of our cyclists at the initial or middle phases of the preparation period these characteristics did not reach their maximal values.

2. The oxygen uptake $(3.85 \pm 0.30 \mathrm{l} / \mathrm{min}$ and $52.6 \pm 3.7 \mathrm{ml} / \mathrm{kg} \cdot \mathrm{min})$ and power output $(296 \pm 28 \mathrm{~W}$ and $4.04 \pm 0.33 \mathrm{~W} / \mathrm{kg})$ at the 
anaerobic threshold intensity of load are in a good agreement with the data received by other investigators. They are useful in the cyclists' endurance performance estimation and monitoring.

3. The oxygen uptake $(2.57 \pm 0.35 \mathrm{l} / \mathrm{min}$ and $35.0 \pm 4.7 \mathrm{ml} / \mathrm{kg} \cdot \mathrm{min}$ ) and power output (182 $\pm 36 \mathrm{~W}$ and $2.48 \pm 0.47 \mathrm{~W} / \mathrm{kg}$ ) of road cyclists at the aerobic threshold intensity load are low due to the test protocol with slow increase of the load and enough time for lactate accumulation in the capillary blood.

4. The mechanical efficiency $(21.9 \pm 1.2 \%)$ and economy of cycling movements
(4.602 $\pm 0.268 \mathrm{~kJ} / \mathrm{l})$ reached their maximal values at the anaerobic threshold, which is the intensity of load specific to road cycling. It proves high homogeneity of mechanical efficiency and economy of movements among the cyclists, and lack of the significant correlation between these characteristics and the power output on the bicycle ergometer $(r=0.19$ and 0.20 , respectively; $\mathrm{p}>0.05$ ).

Acknowledgement. We are grateful to Dr. Digna Jukmane and the staff of Latvian Olympic Team Laboratory for the elite cyclists' aerobic performance diagnostics.

\section{REFERENCES}

Aunola, S., Marnicmi, J., Alanen, E. et al. (1988). Muscle metabolic profile and oxygen transport capacity as determinants of aerobic and anaerobic thresholds. European Journal of Applied Physiology, 57, 726-734.

Bourdon, P. (2000). Blood lactate transition thresholds: Concepts and controversies. In C. J. Gore (Ed.). Physiological Tests for Elite Athletes (pp. 50-65). Champaign, IL: Human Kinetics.

Bulbulian, R., Wilcox, A. R., Darabos, B. L. (1986). Anaerobic contribution to distance running performance of trained cross-country athletes. Medicine and Science in Sports and Exercise, 18, 107-113.

Coyle, E. F. (1995). Integration of the physiological factors determining endurance performance ability. Exercise and Sport Sciences Review, 23, 25-63.

Coyle, E. F., Sidossis, L. S., Horowitz, J. F., Beltz, J. D. (1992). Cycling efficiency is related to the percentage of type I muscle fibres. Medicine and Science in Sports and Exercise, 24, 782-788.

Craig, N. P., Norton, K. I., Bourdon, P. C. et al. (1993). Aerobic and anaerobic indices contributing to track endurance cycling performance. European Journal of Applied Physiology, 67, 150-158.

Deason, J., Powers, S. K., Lawler, J. et al. (1991). Physiological correlates to 800 meter running performance. Journal of Sports Medicine and Physical Fitness, 31, 499-504.

Ferdinandez-Garcia, B., Terrados, N., Perez-Landaluce, J. et al. (2000). Intensity of exercise during road race procycling competition. Medicine and Science in Sports and Exercise, 32, 1002-1006.

Ivy, J. H., Withers, R. T., Van Handel, P. L. et al. (1980). Muscle respiratory capacity and fiber type as determinants of the lactate threshold. Journal of Applied Physiology, 48, 523-527.

Jacobs, I. (1986) Blood lactate: Implications for training and sports performance. Sports Medicine, 3, 10-25.

Lucia, A., Hoyos, J., Carvajal, A. et al. (1999). Heart rate response to professional road cycling: The Tour de France. International Journal of Sports Medicine, 20, 167-172.

Lucia, A., Hoyos, J., Chicharro, J. L. (2001). Physiology of professional road cycling. Sports Medicine, 31, 325-337.
Lucia, A., Hoyos, J., Chicharro, J. L. (2000). Physiological response to professional road cycling: Climbers vs. time trialists. International Journal of Sports Medicine, 21, 505-512.

McArdle, W. D., Katch, F. I., Katch, V. L. (2000). Measurement of human energy expenditure. In: E. Johnson (Ed.), Essentials of Exercise Physiology (pp. 142-155), $2^{\text {nd }}$ ed. USA: Lippincott Williams and Wilkins.

Moseley, L., Achten, J., Martin, J. C. et al. (2004). No differences in cycling efficiency between world - class and recreational cyclists. International Journal of Sports Medicine, 25, 374-379.

Padilla, A., Mujika, I., Cuesta, G. et al. (1999). Level ground and uphill cycling ability in professional road cycling. Medicine and Science in Sports and Exercise, 31, 878-885.

Plato, P. A., McNulty, M., Crunk, S. M. et al. (2008). Predicting lactate threshold using ventilatory threshold. International Journal of Sports Medicine, 29, 732-737.

Saltin, B. (1985). Physiological and biochemical basis of aerobic and anaerobic capacities in man: Effect of training and range of adaptation. In P. Russo, G. Gass (Eds.), Exercise, Nutrition and Performance (pp. 41-78). Sydney: The Sports Sciences and Research Centre, Cumberland College of Health Sciences.

Shave, R., Franco, A. (2006). The physiology of endurance training. In G. Whyte (Ed.), The Physiology of Training (pp. 61-84). UK: Churchill Livingstone, Elsevier.

Sjodin, B., Jacobs, I. (1981). Onset of blood lactate accumulation and marathon running performance. International Journal of Sports Medicine, 2, 23-26.

Tanaka, K., Matsuura, Y. (1984). Marathon performance, anaerobic threshold, and onset of blood lactate accumulation. Journal of Applied Physiology, 57, 640-643.

Telford, R. D., Hahn, Pyne, D. B., Tumilty, D. M. A. (1990). Strength, anaerobic capacities and aerobic power of Australian track and road cyclists. Excel, 6, 20-22.

Yoshida, T., Chida, M., Ichioka, M. et al. (1987). Blood lactate parameters related to aerobic and endurance performance. European Journal of Applied Physiology, 56, $7-11$. 


\title{
PLENTO DVIRATININKŲ IŠTVERMĖS FIZIOLOGINIŲ SAVYBIŲ IVERTINIMAS
}

\author{
Inese Pontaga, Andris Konrads \\ Latvijos kūno kultūros akademija, Riga, Latvija
}

\section{SANTRAUKA}

Tyrimo tikslas - nustatyti informatyviausias kvalifikuotu plento dviratininkų fiziologines savybes, leidžiančias kontroliuoti jų treniruočiu poveikị.

Buvo tiriama 14 Latvijos Olimpinès komandos dviratininkų savanorių, kurių sportinės veiklos patirtis nuo septyneriu iki devyneriu metu (amžiaus vidurkis - 19,3 \pm 1,1 m., vidutinis ūgis $-183,6 \pm 5,4 \mathrm{~cm}$, kūno masé $-73,4 \pm 3,8 \mathrm{~kg}$ ). Jų aerobinis darbingumas tirtas Latvijos olimpinès komandos laboratorijoje parengiamojo etapo pradžioje ir viduryje. Pradinis 27 W krūvis buvo didinamas pamažu kas dvi minutes po 12 W. Širdies ir kvèpavimo diagnostine aparatūra buvo registruojamos elektrokardiogramos ir kvėpavimo rodmenys, tikrinama kapiliarinio kraujo pieno rūgšties koncentracija.

Dviratininkų maksimaliojo deguonies suvartojimo (4,62 $\pm 0,40 \mathrm{l} / \mathrm{min}$ ir 63,2 $\pm 4,8 \mathrm{ml} / \mathrm{kg} \times \mathrm{min})$ ir galingumo (376 $\pm 36 \mathrm{~W}$ ir 5,13 $\pm 0,44 \mathrm{~W} / \mathrm{kg}$ ) rodikliai buvo reikšmingai mažesni, lyginant su kitu autoriu gautaisiais. Parengiamojo etapo pradžioje ir viduryje šios savybės nepasiekè maksimalios reikšmès. Atliekant anaerobinio slenksčio intensyvumo krūvị, dviratininkų maksimaliojo deguonies suvartojimo $(3,85 \pm 0,30 \mathrm{l} / \mathrm{min}$ ir 52,6 $\pm 3,7 \mathrm{ml} / \mathrm{kg} \times \mathrm{min})$ ir galingumo $(296 \pm 28 \mathrm{~W}$ ir 4,04 $\pm 0,33 \mathrm{~W} / \mathrm{kg})$ rodikliai labai panašūs i kitų tyrèjų gautuosius. Šios savybės priklauso nuo centrinių ir periferinių dviratininku aerobinio tūrio mechanizmų ir jos naudingos apskaičiuojant bei kontroliuojant dviratininkų ištvermę. Atlikto tyrimo duomenimis, deguonies suvartota 2,57 $\pm 0,35 \mathrm{l} / \mathrm{min}$ ir 35,0 $\pm 4,7 \mathrm{ml} / \mathrm{kg} \times \min$, galingumas sieké $182 \pm 36 \mathrm{~W}$ ir $2,48 \pm 0,47 \mathrm{~W} / \mathrm{kg}$.

Dviratininku judesių mechaninis veiksmingumas $(21,9 \pm 1,2 \%)$ ir ekonomiškumas $(4,602 \pm 0,268 \mathrm{~kJ} / \mathrm{l})$ pasiekè savo maksimalias reikšmes esant anaerobiniam slenksčiui, o toks intensyvumas būdingas plento dviratininkams. Tai rodo dideli dviratininkų judesių mechaninio veiksmingumo ir ekonomiškumo homogeniškumą tarp dviratininkų, taip pat reikšmingų koreliacijų tarp šių savybių ir galingumo dirbant veloergometru nebuvimą (atitinkamai $r=0,19$ ir 0,20, $p>0,05$ ).

Raktažodžiai: dviračių sportas, aerobinis pajègumas, darbo mechaninis veiksmingumas, aerobinis ir anaerobinis slenkstis.

Gauta 2009 m. sausio 19 d.

Received on January 19, 2009

Priimta 2009 m. kovo 5 d.

Accepted on March 5, 200s

Inese Pontaga

Latvian Academy of Sports Education

(Latvijos kūno kultūros akademija)

Brivibas str. 333, Riga, LV1006

Latvia (Latvija)

Tel +37167266098

E-mail inesepontaga@inbox.lv; inese.pontaga@lspa.lv 